\title{
VOICES OF TRANSITION: OPINIONS AND VIEWS ON KAZAKHSTAN'S ALPHABET REFORM
}

\author{
Robert Parent \\ rparent62@gmail.com \\ Leiden University (Leiden, Netherlands) \\ Роберт Парент \\ rparent62@gmail.com \\ Лейденский университет (Лейден, Нидерланды)
}

\begin{abstract}
Former President of Kazakhstan Nursultan Nazarbayev brought alphabet reform to the forefront of public discussion in Kazakhstan when he announced the transition of the Kazakh language from the Cyrillic alphabet to the Latin alphabet in 2017. Since then, many conversations have taken place across Kazakhstan pondering the necessity of the reform, the best way to implement it, and how to minimize social and financial damage that could possibly be caused by the transition. Context surrounding the background of the reform and alphabet choice is important, and raises questions of identity within Kazakh society. The primary purpose of this article is to present a selection of qualitative and quantitative results from a survey conducted among seventy-five Kazakh speakers and Kazakhstanis. The goal of the survey was to identify their perspectives regarding the reform in the areas of public opinion, education, politics, and linguistics. Knowing how academics and the public perceive the reform allows adjustments to be made which may ease the transition from one alphabet to another.
\end{abstract}

Key words: Kazakhstan, alphabet reform, Cyrillic alphabet, Latin alphabet.

\section{Introduction}

A switch of the titular language of Kazakhstan, Kazakh, from Cyrillic to the Latin alphabet has been a public topic since the decline of the Soviet Union. In April of 2017, an article concerning modernization of the public consciousness was published by then-President Nursultan Nazarbayev on the matter. Entitled "Spiritual Renaissance" (Рухани Жаңғыру), it more concretely set in motion the process of change. In October, 2017, a strategy was released indicating a completed transition by 2025 [1]. Different versions of the Latin alphabet have been adjudicated upon to varying degrees of seriousness, with advantages and disadvantages that can be identified in most cases. Kazakhstan's alphabet transition impacts the economic, political and social spheres of everyday life.

Before proceeding, it should be noted that there have been several developments in the alphabet reform process in the time since the primary research detailed in this article was conducted in 2020. Arguably the largest development is the announcement of a new time frame for transitioning to the Latin alphabet. In January, 2021, the press 
service of Prime Minister Askar Mamin announced that the transition would take place from 2023 to 2031 [2]. This is a wise decision, as complications caused by CovID-19 would have made meeting the previous deadline of 2025 highly unlikely. This new time span also provides a period within which to adapt to challenges that may arise while integrating the Latin alphabet into society. The second major development is that a new version of the Kazakh Latin alphabet has been proposed and submitted for public consideration until May 6, 2021 [3]. It remains to be seen whether this version will indeed be the final one before the transition begins in 2023. The factors of national identity and alphabet choice will be briefly touched upon to provide the reader with context and background for the study of Kazakhstan's alphabet reform.

\section{National Identity and Alphabet Choice}

Kazakhstan's choice of a new alphabet is directly tied to its geopolitical identity and can be examined from several different viewpoints. First and foremost, Kazakhstan's alphabet reform could be seen as strengthening its national identity. This stems from the fact that, following the collapse of the USSR, it would have been difficult for Kazakhstan's governors and citizens to construct an identity utilizing mono-ethnic Kazakh characteristics as they possessed a Russian majority [4, s. 64]. In historical terms, having been culturally centered between the Russian/Slavic and Turkic spheres, Kazakhstan has several avenues to explore regarding the construction of a national identity. In choosing the Latin alphabet, Kazakhstan is at least partially showing support, whether intentional or not, for directing its national identity towards the Turkic world. Selecting the Latin alphabet could further be seen as trying to associate more with globalization and westernization.

It can be said that Cyrillic is a choice for Russia's cultural sphere of influence, since Kazakhstan is currently experiencing Russification as demonstrated by the large number of Russian speakers residing there and the use of the Russian language at all levels of education [4]. According to Kadyrzhanov, it is a question of whether Turkic or Russian identity better defines Kazakhstan's national identity [5, s. 98], implying that Kazakhstan should make its choice based not on which identity is 'better' in general, but rather which one better complements Kazakhstan's own sociopolitical image.

It has been suggested that the continued use of Cyrillic is a hindrance to Kazakhstan's formation of a national identity [5, s. 97]. Furthermore, some see Kazakhstan's use of Cyrillic as a mark of its colonial past, as it was not a free choice of the people, but rather imposed by a totalitarian state [4, s. 58]. It is also noted that the Kazakh Cyrillic alphabet contains 42 letters while the Latin version of the alphabet would be more streamlined with less letters, making it arguably more efficient [6, s. 132].

Those advocating for retaining the Cyrillic alphabet often argue that it is a question of ethnic identity and cultural heritage. In the past, the Kazakhstani government has faced pressure from its large Russophone population to keep the official status of the Russian language almost on par with that of Kazakh [6, s. 129]. It is also pointed out that minorities have stated that both Russian and Cyrillic serve as a 'bridge' be- 
tween nationalities [7, s. 1025]. Kazakhstan has attempted to maintain this bridge in order to avoid interethnic conflict [7, s. 1025]. Cultural heritage must also be taken into account. As over 90\% of existing Kazakh literature is in Cyrillic [7, s. 1025], academics warn that Kazakhstan should avoid making the same mistake that Uzbekistan did when they failed to transliterate a significant portion of their literature into the Latin alphabet [4, s. 68].

While those encouraging the continued use of Cyrillic make valid arguments, the supporters of Latinization have triumphed in the alphabetic tug-of-war. There are three key points in favor of Latinization that many secondary sources agree on. Firstly, it is argued that the Latin alphabet has a universal cosmopolitan character which would allow Kazakhstan to better and more quickly integrate into the global community [5, s. 102]. Secondly, switching to the Latin alphabet is viewed as an essential step towards integrating into the global world of internet and information networks as the Latin alphabet is more compatible with technology and computer programs [8, s. 150]. Thirdly, successful Latinization would more easily facilitate the learning of English and other languages worldwide which use the Latin alphabet [6, s. 133].

\section{Methodology}

The following sections of this article reflect data gathered, which speaks to public opinion on general transition problems as well as matters of reform policy and economics. Kazakhstanis' and Kazakh-speakers' views will be shown [9, s. 32], and the data was collected via a survey distributed through online and academic channels. Seventy-five individuals responded; under $25 \mathrm{~s}$ were the largest group (51\%), followed by those $26-50(33 \%)$, and over 51 (16\%). Respondents were mostly from Kazakhstan (97\%), with the remainder being from Turkmenistan, Mongolia, and Poland (1\% each). In terms of ethnicity, the majority of respondents answered Kazakh (82\%), followed by Russian (8\%), Tatar (3\%), Polish (3\%), and other ethnicities including Belorussian, German, and Turkish (1.4\% each). Almost all respondents were versed in Russian (99\%), followed by Kazakh in a close second (92\%), then English (73\%), Turkish (17\%), German (7\%), and Chinese (5\%). 43\% of answers came from students, followed by teachers or professors (13\%), linguists (6\%), and other professions including economist, analyst, journalist, and waiter, for example (38\%) [10].

\section{Public Opinion on the Alphabet Reform in Kazakhstan}

A selection of relevant findings from the study are detailed below. For privacy reasons, respondents will be referred to by their initials with numerals used if they are repeated. A respondent with specialized linguistic knowledge, Rustem Kadyrzhanov [11], allowed his name to be publicly used. Gender neutral pronouns are used for respondents referred to with initials.

Respondents were more likely to support the reform than not. $47 \%$ were in favor, $33 \%$ against, whilst $20 \%$ had a neutral position. Support for the reform was unequal 
across age groups, and support increases by around $20 \%$ for each generation. $49 \%$ of those under 25 were against the reform ( $31 \%$ for), whilst $52 \%$ of those $26-50$ support it ( $30 \%$ against). No one surveyed over the age of 51 was against the reform. Though only constituting $16 \%$ of responses, this support is arguably important if the demographic expects to face greater difficulties transitioning.

Younger respondents were indeed concerned that older individuals would struggle to adapt. 58-year-old XX1 believes, however, that reform is necessary to modernize, and that younger people will have little problem. XX1's sentiment is echoed by DK, 52. One question specifically contemplated the adoption and use of the Latin alphabet by older groups. Most respondents thought it would be a problem (49\%), whilst $36 \%$ said it might be and the smallest group, $15 \%$, does not anticipate issues. HA believes that respondents are likely to underestimate the older generations, considering common education in foreign languages that use Latin, as well as usage in the realms of hard science.

Most respondents thought that public opinion on the matter was overall negative (40\%), with $35 \%$ expressing a mixed view with only $16 \%$ responding positively. This may be surprising, considering $47 \%$ of respondents personally support the reform. AK1 often comes across negative portrayal of the reform on digital platforms, indicating that a vocal minority may have a disproportionate impact. A key benefit of the reform listed was global integration. Acquiring the Kazakh language will be easier for foreigners, said $34 \%$ of people. $25 \%$ think it will help Kazakhstanis acquire foreign languages in return, such as English. Distancing from Russian influence was listed by $13 \%$ of respondents as another benefit. Such comments indicate a lean towards Western influences, perhaps whilst marginalizing Russian ones. Financial burden is listed as the most basic and serious impediment to reform, said 37\%. Respondents consistently voiced concerns around older generations and their adoption experience, as well as the time involved in a successful transition. The pervasive use of Cyrillic is listed as another key 'problem' here, which will be elaborated upon below.

Questions were posed asking respondents about the role of social media. 71\% of respondents thought that the internet and social media plays either a large role or some role in impacting public opinion. YT indicates that digital platforms allow for criticism and open discussion; a point agreed by $\mathrm{AE}$ who further said that such criticism has produced verifiable results from policymakers. Reform as a political machination in response to Russian influence was the final issue posed in the section. Only $8 \%$ of respondents consider the reform a political statement against Russia, with $81 \%$ expressing the opposite view. $8 \%$ indicate it is possible, and $6 \%$ were unable to answer the question in 'yes' or 'no' terms. Kadyrzhanov has indicated that this may speak to the effect of the Kazakhstani government's official rhetoric on the issue, where authorities insist that the reform is not politically charged. Respondents could not find an easy way around the political subtext here. 


\section{Views on Educational, Political and Linguistic Aspects of the Alphabet Reform}

In terms of Kazakh-speakers transitioning successfully, university students were seen to have a good chance of success $(60 \%) .23 \%$ said that the transition would not be easy for this group. BB said that as these students were likely born following the collapse of the Soviet Union, they should be versed to some degree already in the Latin alphabet. AN agrees, who added that this group should only have to acquire Kazakh-specific letters. MA2 said, rather, it depends on the person. Younger students such as grade-schoolers should also have a relatively smooth transition, said $66 \%$. The younger the student, the more likely they are to succeed, said several respondents.

Of particular concern is how adults can successfully transition, and the government support in place to adequately facilitate this. Considering that most adults are quite busy people, KA1 worries that many will fall behind due to a simple lack of time to learn a new alphabet. Digital resources should be leveraged here by the authorities.

Asked whether it would be more likely for foreigners to have an interest in learning Kazakh, 45\% responded negatively. 35\% indicated that it will stimulate more interest in the language, with the rest undecided. Respondents are concerned that Russian is all-too-comfortable. Many ethnic Russians in Kazakhstan have had the opportunity to learn Kazakh in Cyrillic but have not, said SN, and that a transition to Latin would not motivate a difference. Kadyrzhanov has argued that it is rather more important to develop Kazakh's prestige as a language, beyond simply changing the alphabet. BB argues that a language should bring benefits to the speaker if they are to acquire it fully and use it consistently.

On matters of policy, the respondents had a generally unfavorable view towards the government's ability to handle the reform effectively. In addition, $62 \%$ of respondents said that reform decision was not democratic in nature, standing in stark contrast to the $38 \%$ who responded positively. In the latter group, respondents such as AX3 and ES point to the fact of public discussion as indicating a democratic trend. Response to criticism is just as important, however, and discussion should also be ongoing.

One of the key problems for implementing policy is doing so at a reasonable financial cost. A long-term commitment like an alphabet transition requires careful planning and execution. Over half of respondents anticipate problems funding the reform, with only a quarter indicating that the government would not have a problem. Several respondents commented that the ongoing CovID-19 pandemic guarantees disruptions. Kadyrzhanov states that the consequent fall in oil prices complicates the economic situation further.

More detailed official communications concerning the reform is also something desired. $73 \%$ of respondents were not satisfied with the level of communication or indicated it was lacking entirely, while just $20 \%$ responded that the government is doing enough. Responses could be conflicting. Kadyrzhanov is of the view that communication can definitely be improved, while linguist AX3 wrote that informational strategies had been implemented rather well. It could be that performance is satisfactory in some 
areas, but not others, and ongoing evaluation of new strategies in light of a longer timeline is essential. BB speaks to the complexity of the question, and the inherent problems in the dissemination of accurate public information, such as where it can be modified by the media.

Concerning the linguistics section, questions were asked on how likely a total prohibition of Cyrillic would be. That is, potentially, an effective tool to facilitate transition. $54 \%$ of respondents said that this would not happen, whereas $23 \%$ argued that it will. The rest were undecided. With the context that Russian, and by extension Cyrillic, is already deeply embedded, a ban seems unlikely. On the other hand, the usage of Cyrillic could cause a problem. 54\% of respondents said that the pervasiveness of Russian will make using a Latin-based alphabet difficult. $40 \%$ of respondents disagreed. GM1 does not consider this to be a problem, expressing the view that Russian is already losing ground in Kazakh society.

\section{Conclusion}

This article and the data presented provide a small snapshot as to where Kazakhstanis and Kazakh-speakers stand on the issue of alphabet reform. As the reform is a large-scale endeavor that touches every corner of Kazakhstani society, it is important and worthwhile to understand how the general population relates to the different aspects of the reform. Respondents generally seem to support the change, whilst at the same time intimating that general public opinion is divided on the issue. Interestingly, the greatest support comes from those respondents aged over 51. Benefits and downsides of the transition can be identified, with a general trend in support of the idea that a change could allow Kazakhstan to become more globalized, though at a heavy financial cost. There are pragmatic concerns regarding older adults adapting to the alphabet in a timely manner, while less problems are anticipated among students. Most respondents disagree that the reform is a statement against Russia, but it is seemingly difficult to escape the elephant in the room. Respondents have doubted whether the nature of the initial reform process was democratic, though public discussion on the matter is now clear and ongoing consultation with the public is essential. It is not generally believed by respondents that Cyrillic will be proscribed, but it is possible that the widespread use of Russian will affect adoption of the new alphabet. Successfully modifying a society's medium of visual communication in this way is a monumental task. Perhaps new research examining similar issues detailed in this article could be conducted among Kazakh speakers and Kazakhstanis in several years' time in order to re-evaluate their perspectives as the transition moves forward.

\section{List of references}

1 Татиля К., Кадыржанов Р. Казахская латиница: какой ей быть? // Central Asia Monitor. 29 января 2020 года. [Электронный ресурc] URL: https://camonitor.kz/34076-kazahskaya-latinica-kakoy-ey-byt.html (дата обращения 10.03.2021). 
2 Кульшманов А. Когда начнется переход на новый алфавит в Казахстане // Tengrinews.kz, 28 января 2021 года. [Электронный ресурс] URL: https://tengrinews.kz/kazakhstan_news/kogda-nachnetsya-perehod-na-novyiy-alfavit-v-kazahstane-427326/ (дата обращения 02.03.2021).

3 Представлен казахский алфавит на латинице // Деловой портал Капитал.кз, 22 апреля 2021 года. [Электронный ресурс] URL: https://kapital.kz/gosudarstvo/95096/predstavlen-kazakhskiy-alfavit-na-latinitse.html (дата обращения 02.03.2021).

4 Michelotti V. Переходное время. Alphabet Reform and Identity Politics in Modern Kazakhstan. Al-Farabi 54, no. 2 (2016). S. 58-73.

5 Кадыржанов Р. Выбор алфавита - выбор идентичности // Известия НАН РК, Общественных наук, 5 (2009). S. 97-98.

6 Batyrbekkyzy G. Mahanuly T., Tastanbekov M., Dinasheva L., Issabek B., Sugirbayeva G. Latinisation of Kazakh Alphabet History and Prospects // European Journal of Science and Theology 14, no. 1 (2018): 129-132.

7 Kimanova L. Analysis of Arguments in the Public Debate on the Alphabet Change in Bilingual Kazakhstan // Gaziantep Üniversitesi Sosyal Bilimler Dergisi 10, no. 3 (2011): 1025.

8 Tajibaeva S., Kozyrev T. Statehood, Language, and Alphabet: a Kazakhstan Case Study // Central Asia and the Caucasus 46, no. 4 (2007): 150.

9 Jacob M. Alphabet Reform in the Six Independent Ex-Soviet Muslim Republics // Journal of the Royal Asiatic Society of Great Britain \& Ireland 20, no. 1 (2010): 32.

10 The author observes the distinction between the demonyms Kazakhstani and Kazakh. Kazakhstani is used to refer to anything relating to the state of Kazakhstan or its inhabitants, while Kazakh is used to refer to the language or someone who is ethnically Kazakh.

11 All data presented in this article was originally gathered in 2020 and submitted by the author as part of a thesis for Leiden University's Russian and Eurasian Studies (MA) program. The full thesis can be read here: https:/openaccess.leidenuniv.nl/bitstream/handle/1887/133867/ ParentRobertMAThesisS2444232.pdf?sequence=1 (дата обращения 02.03.2021).

\section{Transliteration}

1 Tatilja K., Kadyrzhanov R. Kazahskaja latinica: kakoj ej byt'? [Kazakh Latin: What Should it be?] // Central Asia Monitor. 29 janvarja 2020 goda. [Jelektronnyj resurs] URL: https:// camonitor.kz/34076-kazahskaya-latinica-kakoy-ey-byt.html (data obrashhenija 10.03.2021).

2 Kul'shmanov A. Kogda nachnetsja perehod na novyj alfavit v Kazahstane [When Will the Transition to the New Alphabet Begin in Kazakhstan] // Tengrinews.kz, 28 janvarja 2021 goda. [Jelektronnyj resurs] URL: https://tengrinews.kz/kazakhstan_news/kogda-nachnetsya-perehod-na-novyiy-alfavit-v-kazahstane-427326/ (data obrashhenija 02.03.2021).

3 Predstavlen kazahskij alfavit na latinice [The Kazakh Alphabet in the Latin Alphabet is Presented] // Delovoj portal Kapital.kz, 22 aprelja 2021 goda. [Jelektronnyj resurs] URL: https://kapital.kz/gosudarstvo/95096/predstavlen-kazakhskiy-alfavit-na-latinitse.html (data obrashhenija 02.03.2021).

4 Michelotti V. Perehodnoe vremja. [Transition Time] Alphabet Reform and Identity Politics in Modern Kazakhstan. Al-Farabi 54, no. 2 (2016). S. 58-73.

5 Kadyrzhanov R. Vybor alfavita - vybor identichnosti [Choosing an Alphabet - Choosing an Identity] // Izvestija NAN RK, Obshhestvennyh nauk, 5 (2009). S. 97-98.

6 Batyrbekkyzy G. Mahanuly T., Tastanbekov M., Dinasheva L., Issabek B., Sugirbayeva G. Latinisation of Kazakh Alphabet History and Prospects // European Journal of Science and Theology 14, no. 1 (2018): 129-132. 
7 Kimanova L. Analysis of Arguments in the Public Debate on the Alphabet Change in Bilingual Kazakhstan // Gaziantep Üniversitesi Sosyal Bilimler Dergisi 10, no. 3 (2011): 1025.

8 Tajibaeva S., Kozyrev T. Statehood, Language, and Alphabet: a Kazakhstan Case Study // Central Asia and the Caucasus 46, no. 4 (2007): 150.

9 Jacob M. Alphabet Reform in the Six Independent Ex-Soviet Muslim Republics // Journal of the Royal Asiatic Society of Great Britain \& Ireland 20, no. 1 (2010): 32.

10 The author observes the distinction between the demonyms Kazakhstani and Kazakh. Kazakhstani is used to refer to anything relating to the state of Kazakhstan or its inhabitants, while Kazakh is used to refer to the language or someone who is ethnically Kazakh.

11 All data presented in this article was originally gathered in 2020 and submitted by the author as part of a thesis for Leiden University's Russian and Eurasian Studies (MA) program. The full thesis can be read here: https:/openaccess.leidenuniv.nl/bitstream/handle/1887/133867/ ParentRobertMAThesisS2444232.pdf?sequence=1 (data obrashhenija 02.03.2021).

\section{Парент P.}

Голоса перехода: мнения и взгляды о реформе алфавита в Казахстане

Аннотация. Объявив в 2017 г. переход казахского языка с кириллицы на латиницу, Нурсултан Назарбаев вызвал оживленную дискуссию в Казахстане по вопросу реформы алфавита. С тех пор в Казахстане было высказано много мнений относительно необходимости самой реформы, лучших способов перехода на латиницу и минимизации социальных угроз и финансовых затрат, которые вызовет этот переход. В статье представлены качественные и количественные результаты социологического опроса 75 казахстанцев с целью определения их взглядов на реформу алфавита в сфере общественного мнения, образования, политических и языковых вопросов. Результаты опроса показывают, что казахстанцы в целом поддерживают реформу, но имеются значительные поколенческие расхождения в этой поддержке.

Ключевые слова: Казахстан, реформа алфавита, кириллица, латиница.

\section{Парент Р. \\ Көшудің дыбыстары: Қазақстандағы әліпби реформасы туралы пікірлер мен көзқарастар}

Aңдатna. Елбасы Нұрсултан Назарбаев 2017 жылы қазақ тілінің латын әліпбиіне көшуін жариялап, Қазақстандағы әліппе реформасы жөнінде қызу пікірталас тудырды. Сол кезден бастап латын әліпбиіне көшу туралы көп пікірлер айтылды. Мақалада әлеуметтік сараптамада алынған 75 қазақстандықтардың әліпби реформасы туралы пікірлері келтірілген. Сараптаманың нәтижелері қазақстандықтардын негізінен реформаны қолдайтынын көрсетеді.

Tүйін сөздер: Қазақстан, әліппе реформасы, кирилл әліппесі, латын әліппесі. 